\title{
Stefek: Leader of the Gang
}

It was by sheer coincidence that Renia Nisker, a young Jewish woman from Ostrowiec, happened to be working as a maid in Włochy for a wellto-do Polish family who lived in a big house. Renia "looked good" - that is, very "Polish." She had been acting as the connecting link between the few of us from our hometown moving about the Warsaw area, and all of us reported back to her whenever possible. It was through Renia that Wala made contact with two other mutual friends from Ostrowiec, Marmula Feffer and Hindzia Szerman, both passing for non-Jews with assumed identities, and both in dire need of help. Marmula, who went by the name of Marysia, and Hindzia, whose assumed name I can no longer recall, had been in hiding in Warsaw, but with the outbreak of the uprising, each had lost her shelter and found herself outside the capital, looking for a roof over her head. Their situation had become precarious, as had mine because of my wretched teacher. We had to find shelter urgently; there was no time to lose.

Wala and I combed the area, desperately looking for a place we could share with Marysia and Hindzia. Ultimately, our attention was drawn to a deserted little house on Kolejowa Street, virtually opposite the railway station. It looked like a jerry-built small bungalow, and bore the year 1938 on the elevation above the front door. The house was still unfinished, with its construction apparently interrupted by the war. The place turned out to be a basic structure, consisting of just two small rooms with no electricity or running water, but there was a well with a pump nearby. The dwelling had no glass panes, just boards nailed to the window frames - ideal, from our point of view. The boarded-up windows made the place look unoccupied and would not attract attention of the prying eyes. There was a rear door that was partly glazed, and provided at least a little daylight.

We tracked down the owners of the property, who turned out to be a middle-aged couple living in a detached house with a garden. It stood on the same plot of land as the bungalow, but farther from the road. We 
knocked on the door, and after the customary Praise Be the Lord was exchanged Wala asked the owner for permission to stay in the vacant dwelling on a temporary basis, as we had no roof over our heads. We had no money for rent, but as they appeared to be reasonably prosperous people, Wala offered to do the housework for them in return, and I would keep the garden tidy. Unfortunately, permission was curtly refused, on the grounds that the place was only partly built and not safe for habitation. We suspected this was not the real reason; it may have been because we had no money for rent. Wala got a little irritated and reminded him, as we were about to leave, that as a Pole it was his patriotic duty to help the homeless from Warsaw, as others were doing at this time. Her reprimand fell on deaf ears.

Still, as we could find no other place, this was an opportunity too good to miss. It was decided that there was no other alternative but to try and enlist the help of my German fishing companion, Ryschard. Soon enough, I managed to locate him, and I told him my sister and I had nowhere to live. I went with him to the owner's house, where he gave the owner a stern warning that unless he opened the place up for us he'd see to it that he was on the next transport of Ostarbeiter to the Reich! This did the trick immediately. Thereafter, the landlord and his wife looked upon us with fear and distrust. This unavoidable course of action had a double edge to it; if the owner ever got suspicious of us, he would not hesitate to exact his revenge and turn us in. It was a risk we had to take, and it was true that any vacant dwelling was supposed to be made available to the homeless from Warsaw.

This is how Wala and I ended up sharing the cottage with Marysia and Hindzia. Marysia had dark hair with pronounced Jewish features, so she had to remain indoors at all times. We took a big risk sharing with the others, but my good-natured sister would never turn a friend away. The landlord never knew there were others inside the cottage besides the two of us. What made matters worse was that Marysia was visibly pregnant; she had been separated from her husband Mietek, who had been taken prisoner during the uprising and sent for forced labour to Germany.

My sister and I started right away to go to church. It was important to be seen doing this, because of the neighbours and the landlord in particular, who must have borne a grudge against us. Thereafter, we went in constant fear of being denounced by him, should he ever 
get suspicious of us. People were jittery and spied on their neighbours, afraid of being implicated in harbouring Jews. On Catholic feast-days it was customary to go to Mass. On entering church, I dipped my hand in the holy water. After crossing myself, I bowed and my sister curtsied. Inside the church we tried to remain as inconspicuous as possible by taking a pew at the back, not wishing to go forward to take Communion. I remembered some of the prayers that Pani had taught me, but I only just recognized the hymns, so my sister and I moved our lips in unison with the worshippers, turning the pages of the missal when they did, and when the congregants made the sign of the cross, we followed suit. We did our best to mimic them, and when the worshippers dropped to their knees or rose to their feet, we did the same; we parroted their every move. At the same time I looked out of the corner of my eye to see if anyone was watching us. During the sermon we were able to relax.

I had by this time gained more confidence and had no problem passing for a Christian boy, but I could not afford to trust anyone and had to avoid making friends who might have gotten suspicious. However, there was a gang of urchins in my neighbourhood of about my age that I could not avoid. I wanted to join them, but they weren't interested. As luck would have it, the ragamuffins started to accuse me of being a runaway from the ghetto! The scamps began to taunt me, and to my utter horror they yelled after me in an exaggerated, mock Yiddish accent: "Żydzie do Getta" (Jewboy, back to the ghetto). This was for me, and indeed all of us at the cottage, a matter of life and death. I didn't dare tell my sister, hoping the problem would soon go away. I didn't want to cause her any anxiety. This was something I had to resolve for myself, that she could not help me with. I had to put a quick end to this serious accusation before it spread further and was perhaps overheard by the wrong person. What made it so alarming was that the boys knew where I lived, and there was no way of keeping out of their way, as I had to be out and about to "organise" food for the group. The thing to do was to somehow win them over and gain their trust, so I could team up with them. The only way to go about it was to somehow concoct a story that would impress them to such an extent that they would want to be friends with me.

Every boy in the Warsaw area was fired up by the uprising, so I decided to invent a tale about my part in it. The first thing was to get them interested and make them want to listen to me. I told them 
that I had taken part in the uprising and had been attached to an AK unit, whose commanding officer was "Młot" (Hammer). This was not his real name, I explained; everyone in the Underground had to have an assumed name, so you could not betray your comrades when captured. One bright spark asked what my code name was. I had not thought of that one, and instinctively thought of my dog, Dynguś. I went on to recount how I had been active in the uprising as a runner and ammunition carrier for the AK, until I was cut off from my unit when my district fell into German hands and an early end came to my exploits. Later, I told them, I'd managed to escape from a holding centre, ending up in Włochy. The boys took much pride in the uprising, but so soon after the event they knew little about it, so it wasn't difficult to impress them. Over the next couple of days I tried to gradually relate to them all I knew. What they were really keen to hear were examples of Polish bravery. The boys sat cross-legged on the ground, listening carefully, and eagerly swallowed every word, wanting to hear more and more. I described the street fighting and the different equipment in the arsenal of the AK, with which I was somewhat familiar. Being interested in weaponry, I could identify the equipment on both sides, and imitate the sound they made when fired. I was able to mimic the punctuated rattat-tat of the Spandau heavy machine-gun and the sound the Mauser gun made. I told them about the underground army's favourite piece of equipment, dropped from the air in great numbers by the British-the PIAT anti-tank projectile-firing rifle that was most effective in knocking out German Panzers. They were pleasantly surprised to hear that the AK managed to capture German tanks and turn them on the enemy. I also told them about the "Krowa," which really made them laugh. They were fascinated by the enemy's miniature robot-tank, the "Goliath," which was packed full of dynamite and which the "Fritzes" directed by remote control against the defenders' pillboxes and barricades. But what really pleased them was when I told them that these infernal robots could be sent off-course by a single well-placed Polish rifle shot!

The boys were very impressed by it all and decided that I could not have known all this unless I was there and had taken part. I had, of course, learned most of this while in Warsaw, following the progress of the fighting and listening to other people's conversations. There were in fact such boys as I pretended to be enlisted by the AK; being small, they were less conspicuous and more suited for crawling through holes 
in bombed out buildings to relay messages and to carry ammunition. I produced a silver eagle badge out of my pocket, which represented the White Eagle emblem of Free Poland. I had proudly worn it on my beret, I told them, but it was prohibited to display this now, and I put it back in my pocket quickly. They were all keen to touch it. I also recalled songs adopted by the insurgents that became songs of the uprising, like "Serce w Plecaku" (My Heart in a Kitbag), which I had learned from Wala, who liked to sing and knew all the popular songs. Soon enough, my stories did the trick, and the boys became envious of me and full of admiration, wishing they had also been there.

As I was the most savvy and resourceful of the boys there, I soon took charge of the gang-they had never had a leader before. They now considered me one of them and were happy to follow me. All the taunts stopped, and I would never again have to face accusations of being Jewish from them. True to street-gang tradition they all had nicknames, mainly deriving from the boys' appearances. I hardly knew their real names. There was Zabak (Goofy), who had long incisors, Dziobak (Spotty), who had a pock-marked face as a result of chicken-pox, and Ślimak (Snail), who had a gammy leg and couldn't run fast, and ironically I was Żydek (Jew-boy). They didn't mean any harm by it; every boy had to have a nickname, and they didn't see anything wrong in calling me that. Perhaps they innocently thought the label suited me for some reason other than that they took me for a Jew. At first I thought it best ignored, but the harsh sound of $\dot{Z} y$ dek was like a dagger through the heart every time I heard it. But as I was now the leader of the pack, I had the power to discourage any nickname, and certainly this one, and in time they dropped it, calling me simply "Stefek." I now had friends, which I'd never had before. I wanted pals like them to give me the legitimacy and cover I needed - these relationships would be my guarantee of survival. Being part of a gang also helped me to "legitimately" purloin food-which was quite important as I had several mouths to think of. From then on I went unhindered and was not picked on by any street kids. I wore a chain around my neck supporting a large medallion of St. Stefan, my patron saint, I claimed. It was prominently displayed outside my vest, and I hoped this would help to demonstrate my deep Christian devotion.

The one activity I could never join my pals in was swimming in the nearby ponds, as they swam with nothing on. I had to own up to the "fact" that I couldn't swim and that I hated water. "I even dislike washing," 
I told them. I could not have turned down their challenges indefinitely, but luckily the summer was almost over, and once the weather grew colder there was one less problem to worry about. There was no school, so we were free to roam, foraging for food, pilfering a little here and there: scrumping fruit from orchards, digging up potatoes, and pulling carrots and turnips from the fields. Some of the boys even lifted from market stalls, but I tried not to resort to that, at least not yet, while there were things to be had from gardens.

The boys came from poor homes, and the war imposed even greater hardships on them. Their endeavours helped to sustain their families. At times, we would end up being chased off by farmers with hayforks, having to make our getaway across fields of bindweed and stinging nettles. Poor Ślimak, the Snail, was always the one to get caught and given the "prize" of a tanned hide. My face became bronzed and weather-beaten as a result of all the time we spent outdoors. I blended in well with my gang; I sounded like them, adopting their local singsong twang, and looked grimy like them in my tattered clothes. I wore my peaked cap at a jaunty angle and smoked the odd dog-end, which I really hated, in order to appear like a cwaniak (artful dodger). The cigarettes we would cadge off Wehrmacht soldiers by holding a hand out, and begging in German-Polish "speak" "Kamerad, Kamerad, Papierosy." Oval-shaped German cigarettes were highly regarded and a valuable trading commodity. I started a small production going, making low-cost cigarettes out of cigarette ends collected off the streets. I trimmed the stained stub-ends with a razor blade, emptied the clean tobacco into a tin, and mixed it with cheaper machorka to make it go further. I had a device to inject the blank giłzy (filter-tips) with tobacco. Astute smokers used a pin to smoke them to the very end, saving what they could-only Germans discarded long cigarette-ends. Senior officers smoked highly-prized gold-tipped cigarettes, and they could afford to smoke about half of each one, throwing the rest aside. The kids would fight for them in the dust. In wartime, some people would forego food in favour of a smoke. I sold the "recycled" cigarettes on a street corner where people mingled if they had something to sell or exchange. With several mouths to feed, I was only interested in food.

Our place had no electricity, and we had no money for paraffin for the lamp, but fortunately we did have a small cast-iron wood-burning stove inside the hut. There were no windows, but some daylight came through the partly-glazed door. At night lighting could only be provided 
by candles. These I collected from graves at the local cemetery. This was a secret I never shared with my pals, as they would never have approved of filching from the Catholic cemetery. Stealing food was fair game, but this, I knew, they would have considered a sin. I also made candles from leftover bits of candle-wax, likewise taken from the graveyard. These I melted down and poured it into a wooden mould, before the mixture set, I inserted a thin piece of string for a wick, then poured the rest of the wax on top. My home-made candles were more square-shaped than round, burned rather quickly, and had a tendency to drip and flare up, but they nevertheless went some way to solving our lighting problem. However, fuel for heating and cooking was of great concern, as winter was fast approaching. The only thing we still had for the pot was a small store of potatoes and vegetables, which we had to ration severely, and no meat or stock, with only the odd packet of army-issue margarine, courtesy of Ryschard.

In wartime, the gloomy, harsh winters were the most difficult to endure. The sixth winter of the war was drawing near, and without heating one could barely survive the harsh Polish winter. As time went on, more and more responsibility fell on me to provide for our small band at the cottage, and things got much harder for me. It was unsafe for young adults to go outdoors, and Wala was forced to stop doing odd jobs, making things even more difficult. She had not been able to replace her identity papers, and as she was a young woman she also ran the risk of being rounded up and taken to Germany for forced labour. Besides, my sister was too pretty to be out and about; she would have been in danger from the lawless ex-Russian auxiliaries stationed in the town. I now kept "my band" locked in with a padlock, making the place look unoccupied before setting out on my daily quest in search of food.

Włochy had never had many shops, and those that had existed were now shuttered, as there was no food to be put on the shelves. To buy food, there was only the black market, and farmers in the countryside for those who had the means. Some people lived by bartering their possessions, but we had neither money nor anything to barter with. Coal was unobtainable, since it all went into the German war effort. The cold was setting in early and without heat our frostbitten feet would begin to ache, then swell up and turn blue; this was the first sign: after that you could simply fall asleep and never awaken. Dried cow-pats made for excellent fuel: unlike wood, they burn nice and slow. Others, however, 
had the same idea, and any cattle dung soon disappeared from the fields. Anyway, when the snows come, cattle are taken under cover. People cut down their trees or collected twigs and brushwood in the countryside. Unlike other places, Włochy never had a ghetto, so there were no empty homes to tear down for firewood. There were plenty in Warsaw, but that was strictly out of bounds.

I noticed that German coal trains passed regularly along the track running parallel with the main road, just across the street from our hut. Pitiable old grannies, bent double with age, could be seen along the railway track, trying to dig up bits of coal and coke from the ground by picking over the soil with sticks. Others tried to eke out some heating fuel from the coal-blackened earth with sieves, separating the slag from the pebbles and dirt. There had to be, I thought, a better way of "requisitioning" some badly needed coal. I observed that coal trains slowed down as they approached Włochy station, but the train didn’t stop there. Włochy station was permanently closed, as it led only to Warsaw, which had been totally depopulated and declared out of bounds to civilians. Only German personnel or people with German Passierscheinen were allowed into the station. Once past, the train would pick up speed again. I was about to perform a feat which so endeared me to my gang that Stefek would forever become the object of their admiration as a man of derring-do. I ran along the rear of the train, and as it slowed down I jumped on the step of the last wagon and pulled myself up the foothold and over the wagon to where the coal was heaped high. Then, lying on my back, I pushed the coal over the side with my feet as quickly as I could. As the train pulled into the station, I spread-eagled myself flat on the coal so I would not be seen by the sentries at the station. Stealing Third Reich property was tantamount to sabotage, and I risked being shot. Once past the station, I reversed the routine, shoving more of the coal over the side before clambering down as the train made to gather speed. Meanwhile, the rest of the gang ran alongside the track, collecting the coal in sacks, dragging them as they went. Later on, with a blackened face and covered head to toe in coal dust, I shared out the haul and also spared some for the bent-over babushkas who had been scratching at the soil with their sticks. The grateful old ladies showered me with blessings in the name of "Sweet Jesus." My new activity went some way towards easing our heating problem. We now had an inexhaustible supply of fuel, courtesy of the Third Reich! 


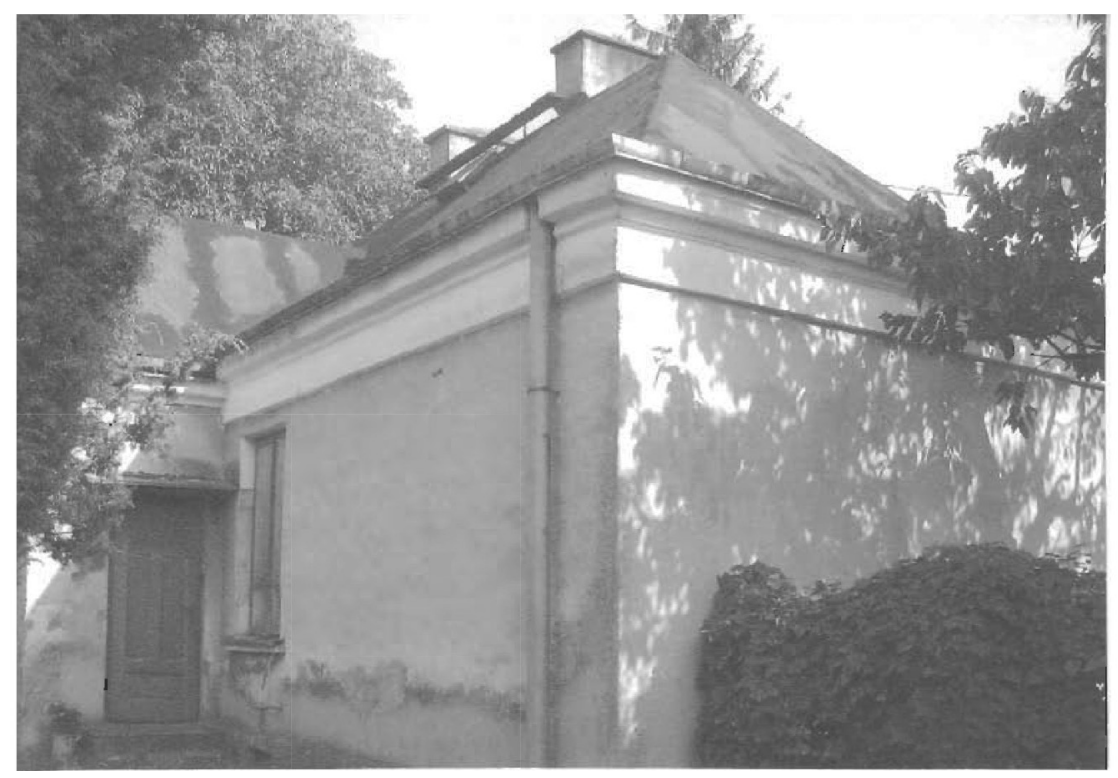

The tiny cottage in Włochy we and our friends sheltered in.

We only had the use of this rear door, everything else having been boarded up.

An additional problem we encountered when winter set in was, surprisingly, drinking water. There was no plumbing or running water in our dwelling, as it was only partly built, but there was a well in the landlord's garden which we had access to. Later on, during hard frosts, this became a problem. Although the hand-pump was lagged with sacking, it was not enough to stop it from freezing up. We stored all the water we could for drinking, cooking, and everyday usage, but we didn't have enough receptacles to store enough water for five people for long. For washing, we melted down snow. Luckily, we had a very basic cesspool lavatory at the cottage, though without the flush mechanism. Fortunately, it never filled up, but the room had a permanent reek to it. I never added to the problem: as I was always out and about, I got into the habit of doing what boys in the country normally did.

Our contact Renia Nisker at some point that winter informed Hindzia that her husband Chanina, from whom she'd gotten separated in Warsaw, had sent a message to her that he was at the nearby Ursus or Pruszków transit camp with other prisoners from the Warsaw uprising. They were transported daily in sealed freight cars through 
Włochy station to Warsaw, to work on defence fortifications and the clearing of rubble. Hindzia was concerned for her husband, who was in great danger because of his Jewish appearance; his fellow prisoners were antagonistic to him. Hindzia was anxious for him to join us at the cottage, if only a way could be found of getting a message to him to encourage him to escape. We had a suitable hiding place for him in the hut, a small cellar-cum-larder below the floor, with a hinged tilt-up door.

The train carrying the prisoners only stopped at the station for a few brief minutes, with no one allowed on or off. I took it upon myself to try to get a message to Chanina, but I needed an excuse to get into the station, and I didn't know how to go about it. It was "little" Hindzia who came up with the idea of pretending to be a cigarette seller and sneaking in herself. I acquired a shallow wooden box, to which I attached a strap to suspend it from the neck, like a cinema usherette. On the box I placed some hand-rolled cigarettes, as well as empty packets and some boxes of matches, which were not difficult to obtain. As cigarettes were scarce and expensive in wartime, they were sold singly. Assuming her role, Hindzia, being small and petite, attempted to get into the station, but was turned away. A day or two later, I thought I would I try my luck. I made for the station with the tray around my neck and approached the two sentries standing watch. I asked them, pointing at my tray, if they would allow me inside, "to flog a few smokes." The sentries were rather amused by my cheekiness, shrugged their shoulders, and waved me past.

As the train slowly pulled in, I ran alongside it shouting "Zapałki! Papierosy!" (Matches! Cigarettes!) for the benefit of any German guards. As I darted from wagon to wagon, I called out in a low voice for "Jan Wójcik," the name Chanina went by. The freight cars were tightly packed with standing prisoners and I could not locate him. There was a big commotion up and down the train as I went: men shouted and begged me to pass on messages they held in their outstretched hands, but I had no way of helping them all. A couple of days later, I repeated the same routine, running alongside the train. This time, however, Jan was near the opening, looking out for me. He had apparently heard me call out for him last time, but had been unable to get near the opening of the tightly packed wagon. He stretched his arm out through the small, barred-over window high up in the wagon's wall, trying to pass me a note. But as I couldn't reach up to it, he dropped it on the platform. 
I had realized ahead of time that this could be a problem, and had come prepared with Hindzia's note attached to a stick. He was able to reach it. In the shadow I was just about able to make out his face. I knew Chanina; he had been a Jewish policeman in the ghetto. He was a good man, known to help others, and now I was glad to be able to help him.

In Jan's message to his wife he wrote that his situation had become very dicey because his fellow prisoners were hostile to him, and that he could be betrayed to the Germans at any time. The note from his wife that I'd handed to him contained precise directions as to how to find his way to our place should he manage to escape. A few days later, Jan appeared at our door in the middle of the night, overcome with exhaustion, having trudged in the deep snow from Pruszków to Włochy, keeping off the main roads. Thereafter, he remained hidden inside and never ventured out again until the war was at last over. If there was anyone at the door, or any disturbance outside, he and Marysia would dive into the cellar, and in a matter of seconds we would cover the trapdoor with a mat and put a small table on top. I felt proud that I had a hand in helping a desperate man who would have been detected, sooner or later, or denounced to the Germans by his fellow prisoners.

Personally, I now felt ever more confident of surviving the war, even if it were to drag on another year, especially when I was operating with my gang. I even stopped thinking of myself as Jewish. However, by all staying together in the one place, we were all disregarding a basic wartime rule of not endangering one another. In the event of a knock at the door, there would be no escape for any of us. We took a terrible risk by staying together with Chanina, an adult male whose Jewishness was unmistakeable. Tall and handsome though he was, he had very pronounced Semitic features, with a shock of black wavy hair and a prominent nose-almost like the caricature of a stereotypical Jew. On the one hand, I felt more secure than ever when out and about with my gang, but on the other, I felt unsafe inside my own hut. It would have been so much safer to "operate" with just my sister, as we had been before, but we were tired of the long struggle and felt we had reached the end of the line, taking ever-greater risks. There was no way out now; the five of us were 
comrades in adversity, linked by a common fate, we either all lived together or all went down together. ${ }^{11}$

As winter tightened its grip, there was no fruit left in the orchards, and it became increasingly difficult to find food. The ground was covered by a thick blanket of snow and frozen solid beneath it. There was nothing to be had from the fields either, as all had been gathered in before the onset of winter. All I could find were some withered Brussels stalks, devoid of any sprouts, protruding from the windswept, snowy ground. Any potatoes or root vegetables left in the ground would reduce to an inedible mush when thawed out. Our food stock was depleting by the day, and Marysia was of great concern. Being pregnant, she was in need of nourishing food. We had right from the start pooled all our money together; my sister and I never had much, but Hindzia, being a thrifty little business woman, somehow always managed to scrape a few coppers together when required. However, the kitty was now virtually empty, with every grosz or pfennig spent on food. All my previous sources of supply had dried up because of the weather.

We now got very worried about surviving the long winter. Apart from white beets, all we had left stored in the cellar was a small quantity of mouldy potatoes, which we had to ration severely. We ate them with the peels, but after cutting the blight away carefully we didn't have much left. We still had a reasonable stock of sugar beets, which had been plentiful in the fields in late autumn, before they too had beem harvested. We ate the beets raw at times, but mostly we had them cooked, and drank the sweet liquid they were boiled in, until we were well and truly sick of them. Fortunately, my German friend Ryschard still helped out now and then, but not as much as before. It depended on what he could get. There was no more American milk chocolate, dropped from the sky, to be had, but what was more beneficial was that he passed on

11 Of the Włochy group, Hindzia and Chanina (Jan) Szerman, who changed their family name to Malachi, live in Hadera, Israel, where Chanina became a poultry farmer in a co-operative. He has since passed away. Renia Nisker, who changed her family name to Nir, lives in Tel Aviv. Marmula (Marysia) Feffer lives in Rio de Janeiro, Brazil. She was reunited with her husband Mietek, from whom she had become separated during the Warsaw uprising, after the war. He was taken with other Poles from the uprising to a slave-labour camp in Germany where he survived. He has since died. Fortunately for Marmula, liberation came in the nick of time for a son Kubush (Jacob) to be born. 
some army rations whenever he could. Once he came up with some tins of Wehrmacht-issue cheese-spread, most of which I exchanged for bread in the unofficial market to make it go further. I don't really know why he helped the way he did, apart from feeling sorry for the young "orphaned urchin" who often went hungry and was forced to scavenge for food. He may have guessed that I had other mouths to feed, besides my sister, but he never asked any awkward questions. He may even have suspected what I was up to-it wouldn't surprise me; Ryschard was no Nazi, and I had always felt he could be trusted.

One day, word spread that a tired old nag had dropped dead in the street. I decided to join the fray, entering the crowd that was stripping the animal of its flesh, but by the time I had managed to get near enough to the carcass with my knife, the scraggy old horse had already been stripped clean. Only the bare ribcage remained. In the free-forall, I managed to make off with a couple of the horse's ribs, virtually devoid of flesh. In the fracas, I got covered in the horse's blood and dirt. Nevertheless, the ribs produced a nutritious, if watery, consommé, which was a real life-saver. People went hungry if they had nothing of value to sell or to barter with. There were impromptu street bazaars, without stalls or tables, where one could stand and sell, holding up items for sale in their hands, ready to run if need be. I remember one particular very large woman who stood in the market. She wore several layers of clothes, which made her look even bigger than she was, and was wrapped in a large crocheted shawl with fringes in the style of peasant women. She was selling hot soup from a cauldron standing on some bricks and flaming tinder. The appetising, thick soup was always the same, containing flaki, or tripe, cut into thin white strands like noodles. Only those who could afford to buy were allowed to stand near the steaming cauldron to warm their hands while they slurped the piping-hot soup out of chipped enamel bowls. I had to make do with just the aroma. The smell was divine!

Rumour had it that there were rich pickings to be had in the Warsaw ruins. The inhabitants of the homes there had been either killed or driven out, and plentiful dried goods had been left in sculleries and cellars. The city had been completely emptied of people and designated a closed military area, with German soldiers manning the defences along the Vistula, facing the Russian lines on the opposite bank. It was forbidden to enter any part of the depopulated city, under pain of death, but 
by this time I was so desperate that I was prepared to take the risk of going into the obliterated city to look for food. At the barrier checkpoint out of Włochy, on the road leading to Warsaw, I observed that army supply trucks headed in, and the same vehicles returned empty later on in the day. I decided to disregard the danger and try to jump a ride to Warsaw on the back of a German truck. Then I could try to recce out the deserted city for some desperately needed sustenance. If I could only pull this one off, it could save our group from possible starvation.

One early morning, after saying goodbye to my sister, I told her that I had a busy day ahead of me with my gang, and that she should not expect me back early. I took a long detour round the checkpoint barrier where the trucks had to stop for inspection, then rejoined the road further along, where I stayed hidden behind an obstacle near the road, waiting for a slow-moving lorry to appear. Because of the shortage of diesel fuel, some of the German trucks had to resort to a wood-burning system, with the engines adapted to run on timber logs, or rather the gas extracted from the timber. These trucks were easily recognised by the large metal cylinder mounted beside the driver's cab. Luckily, these were very slow to accelerate, and when the right lorry approached, I sneaked up behind, hinged my fingers on the rear tailboard, and hoisted myself onto the truck, below the canvas flap. To my surprise, the lorry was fully-laden with pallets of mortar shells and other munitions which helped to conceal me from the driver in front. As I didn't know the final destination of the vehicle, I decided not to venture too far into the city centre, in case I had to make it back on foot through the ruins.

This foray brought back memories of home; it reminded me of the carefree rides I used to take on the back of dorożkis in Ostrowiec, which now seemed so long ago-my life there was a distant memory. I often dreamed of home, about my parents and brothers and the happy times, now long gone. A lot had happened since-it had been five long, miserable years since the war began. I had also changed in that time. I could hardly believe what had become of me; I had grown into a scavenging young wretch who my parents would scarcely have recognised.

The truck wound its way slowly along the meandering path in between heaps of rubble and piles of bricks. When the vehicle reached a certain spot and almost came to a halt because of some obstacle, I quickly lowered myself from the tailboard and darted away to a concealed spot. Looking around myself, I was astounded by the 
dreadful scene: the once beautiful city was reduced to a scene of utter desolation. From where I stood, all I could see was a vast landscape of empty shells and ruins. I found myself all alone in a wilderness of burnt-out buildings and heaps of rubble as far as the eye could see, totally devoid of people. It was rather eerie; there wasn't a living soul to be seen. A world where silence and desolation reigned. Apart from the odd rat scuttling by in my path, there was no sign of life. I fantasized that I was not only the last Jew left, but also the last human being, reigning over a vast emptiness and crumbling ghostland, as if after an apocalypse.

Some years later, reading the novel On the Beach, by Neville Shute, I imagined it to be like the scene from Warsaw, when I pictured myself the last human left alive after a nuclear blast. It was hard to believe that these ruins were once part of a beautiful city; all that was visible now were jagged shells of buildings with only their chimneys jutting out. The interiors were gutted. The only sign of life I saw was the occasional German military vehicle moving along the winding path where the truck I'd jumped off of had stopped. As I was picking my way through the ruins, I went numb with fear when I spotted a large skeletal dog in the distance, no doubt scavenging for food like me. Although I had always loved dogs, I tried to keep well clear of it so it would not pick up the scent and perhaps latch on to me, leaving me unable to shake him off. The sound of a dog barking could have attracted the attention of any Germans in the immediate vicinity and perhaps even stopped me from getting back onto the lorry. Besides, I had nothing to share with the dog; I was just as hungry.

I knew it was best to look for food in an area that was recaptured by the Germans early on in the uprising, as districts that had held out for any length of time would have no food left, having been stripped bare by the starving population. So I decided to concentrate on the neighbourhood of Koło, which was nearby and not far from Wola, where my sister and I had been during the uprising about four months before. Koło, which means "wheel" in Polish, was a modern housing estate comprising a number of uniform blocks built in a semi-circle-hence the name. Surprisingly, some of the buildings in this area were still standing, and that was why I headed for it. Some of the buildings had suffered considerable damage, with only gutted shells remaining. Where it was possible to get inside, I often came across the odd rotting corpse in my path, 
lying on staircases and in basements. I had become hardened to seeing the dead; it was nothing new to me, but coming across a fully clothed, putrefied body with bony hands, not quite reduced to a total skeleton, with protruding white dentures and sunken eye-sockets staring at me was a bit ghostly, to say the least. The stench was overpowering.

The homes looked as if they had been left by people departing in great haste, with pots on stoves, dishes and broken plates on tables, and everything covered in a thick layer of plaster-dust or debris. Tangled steel girders and wooden beams were hanging from ceilings. In one place, a section of a staircase was left clinging to the wall, with the rest having collapsed, and I could go no further. Chattels, broken furniture, toys, clothing, single shoes, lay strewn about the place. The desolate scene was terribly reminiscent, I thought, of the deserted ghetto back home in Ostrowiec, after the deadly German Aktzia had swept through it.

Searching the cellars and larders, I found dried beans, oatmeal, kasza, and the like, still safe to eat if it was inside tin containers and jars that the rats hadn't gotten to first, but I found nothing that would immediately assuage my hunger. I was hoping to find valuables that I could barter for fresh food on the market, but never found anything of value that was small enough to be carried away. In wartime people take their riches with them or bury them in the ground, making them impossible to find. Sifting through every nook, I came across a rather nice, if somewhat large, leather windcheater, which I was to wear all the time, and a navy-blue skicap with earflaps that I treasured, as it was fashionable at the time and good for keeping out the cold. I only took clothing that I liked and could wear; otherwise I only took dried food. I found enough of it; I just couldn't carry it all away. I stuffed my pockets and filled socks I had found among the wreckage by stuffing them until they resembled sticks of salami and then tying the ends. I fastened some to my waist; others I hung from my neck and shoulders, leaving them to dangle, in order to keep my hands free. I must have looked very strange indeed.

By late afternoon I started on my way back, making for the same spot where I had jumped off the lorry in the morning, at a point where the road narrows to a sharp bend. I lay there on a pile of rubble, reclining on my back with the sausage-bags beside me, waiting for a slow-moving lorry to appear so I could follow the same routine as in the morning. Despite the weight, with my hands free I just about managed to get off the ground and clamber into the rear of the truck. As the lorry was 
empty, the canvas flap was rolled up at the back, which made it easier for me to get in. It was also safer now; as it was beginning to get dark, I was less likely to be spotted by the driver. However, being festooned with the bulging sausage-like bags dangling from my shoulders and waist, I found my movement impeded, making it difficult to jump off the lorry when I was near the checkpoint. Thankfully, it all went without a hitch. Once out of Warsaw, I managed despite the weight to lower myself from the truck before reaching the barrier, thus avoiding the sentries at the checkpoint. From there on, I continued on foot. It would have been too conspicuous to walk loaded down with the sausage-like bags swinging from side to side, so I stopped to hide the hoard under some bricks, to be carried away piecemeal.

We now had a modest source of dried food and oatmeal. Cooked together with the beets and any mouldy vegetables and frozen potatoes we had, this went some way to ease our hunger. I had to keep my exploits secret from my sister, as she would not have allowed them. To explain the sudden appearance of life-saving provisions, the story told at the cottage was that I must have discovered a robbers' cave and been deft enough to steal from the thieves! I said nothing to dispel the notion and it was left at that, for I could not afford to let on. About two weeks later, when our stock started to run low, I had to risk another expedition, going back to more or less the same spot where I had been before. To make things easier, I took away less this time. This modest supply of food became a life-saver, particularly for Marysia, who was now heavily pregnant. The nutritious food undoubtedly helped her condition. However, as her confinement was drawing near, we feared the risk of her having to seek medical help. With her typically Jewish features, this was a disaster waiting to happen that endangered all of us.

Time passed slowly while we waited for news about the war. I was still roaming with my gang, except for my forays into Warsaw, which I could not afford to share with them as they were not something that could be done as a team, and I doubt if their situation was as desperate as mine. Otherwise, I was always out on the streets, loitering with my chums, always on the lookout for an opportunity to "organise" food by any means, even resorting to stealing. I got used to that, too.

I now felt ever more confident and no longer fearful of the Germans, but still on guard against certain bad people. The general Polish population had its own problems with the Germans, and in trying to ward 
off hunger and survive the severe winter, so they appeared to have stopped actively looking for Jews in their midst. In any case, there were hardly any left. They were glad the Germans had gotten rid of them, but their animosity to the absent Jews was so deeply entrenched that they were still obsessed with them in their everyday conversation. Ironically, they now had a commonplace saying they kept repeating: "First the Jews and then us!" By this they referred to the prevailing situation and the harsh treatment meted out by the Germans. In spite of this, which one might have imagined would cause a feeling of kinship, their fixation on the non-existent Jews never really abated. Perhaps it was just their manner of speech. Whether they were in the marketplace or in another place where people gathered, the Poles' gossip invariably turned to Jews. I often had to stand there and listen with my ears pricked up, trying not to show any emotion as they went on to curse the Jews blindly. They blamed them for all their troubles: the collapse of the uprising, the failure of the Russians to come to their aid, and more; and insisted that Jews sided with the Bolsheviks, that Jews were behind the black market, and so on. They were convinced that there was a Jewish conspiracy behind everything, though you would have been hard pressed to find a living Jew-I hadn't come across anyone outside of our group who I would have suspected of being Jewish since I had left Ostrowiec. 